\title{
Pelatihan Pertolongan Pertama pada Kegawatdaruratan di Sekolah Children Centre Brawijaya Smart School Malang
}

\author{
Bintari Ratih Kusumaningrum ${ }^{* 1}$, Annisa Wuri Kartika², Ikhda Ulya ${ }^{3}$, Muladefi Choiriyah4 $^{4}$ \\ Dewi Kartikawati Ningsih ${ }^{5}$, Efris Kartikasari 6
}

1,2,3,4,5,6 Jurusan Keperawatan Fakultas Kedokteran Universitas Brawijaya

\section{A R T I C L E I N F O}

Article history:

Received 20 August 2018

Received in revised form

15 September 2018

Accepted 24 Oktober 2018

Available online 27

November 2018

\section{Kata Kunci:}

Pertolongan pertama pada kegawatdaruratan, guru

TK, pencegahan kecelakaan, sekolah

Keywords:

First aid for emergency,

kindergarten teacher,

accident prevention, school

\begin{abstract}
A B S T R A K
Anak-anak merupakan usia yang rentan mengalami kecelakaan atau cedera karena keingintahuan tentang hal disekitarnya, terutama anak usia pra sekolah. Kecelakaan tersebut bisa dicegah, jika di sekolah atau dipenitipan anak hal ini bisa di cegah oleh guru atau pengasuh anak, jika di rumah bisa dicegah oleh orang tua. Pencegahan dan pertolongan pertama pada kecelakaan sangat penting dilakukan di sekolah dan di penitipan anak untuk menciptakan lingkungan yang aman untuk anakanak. Pada program ini dilakukan program safe community pada sekolah bertujuan untuk mengetahui praktik pencegahan dan P3K,serta melatih guru dalam P3K. Guru yang dilibatkan sebanyak 10 orang. Metode pelaksanaan kegiatan yaitu diskusi kelompok terfokus, penyuluhan dan pelatihan P3K. Hasil yang didapatkan yaitu para guru telah melakukan praktik pencegahan dan terdapat peningkatan pengetahuan penanganan kegawatdaruratan di lingkungan sekolahnya dengan indicator terdapat peningkatan nilai post test dari 6,1 menjadi 8,5. Adanya program ini dapat meningkatkan pengetahuan dan kepercayaan diri mereka serta memotivasi mereka untuk terus belajar tentang P3K dan menyamakan persepsi dengan orang tua siswa tentang pertolongan pertama pada kecelakaan di sekolah.
\end{abstract}

\section{A B S T R A C T}

Children are ages who are prone to accidents or injuries because of curiosity about things around them, especially pre-school age children. This accident can be prevented, if at school or in child care this can be prevented by the teacher or carer of the child, if the parents can be prevented by the parents. Prevention and first aid in accidents is very important at school and in child care to create a safe environment for children. In this program a safe community program was carried out in schools aimed at identifying prevention and first aid practices, as well as training teachers in first aid. The teacher involved was 10 people. The method for implementing activities is focus group discussions, counseling and first aid training. The results obtained are that the teachers have carried out prevention practices and there is an increase in knowledge of handling emergencies in the school environment with indicators that there is an increase in post test scores from 6.1 to 8.5. The existence of this program can increase their knowledge and confidence and motivate them to continue learning about first aid and to equate perceptions with parents of students about first aid in school accidents.

\footnotetext{
* Corresponding author.

E-mail addresses: bintari.ratih@gmail.com (Bintari Ratih Kusumaningrum)
} 



\section{Pendahuluan}

Kecelakaan atau cedera merupakan kejadian yang ada disekeliling kita. Kecelakaan bisa terjadi di rumah, sekolah, penitipan anak, atau di jalan. Anak-anak merupakan usia yang rentan mengalami kecelakaan atau cedera karena keingintahuan tentang hal disekitarnya, terutama anak usia pra sekolah yaitu usia 0-6 tahun. Anak-anak usia tersebut rentan sekali mengalami kecelakaan di sekolah. Kecelakaan bisa berupa jatuh, kejatuhan mainan, menelan mainan-mainan kecil, tersengat listrik, terkena air panas dan tenggelam (Lindqvist, Timpka, Schelp, Risto, 2002).

Kecelakaan dapat menimbulkan luka yang serius bahkan kematian jika tidak diatasi dengan benar. Tetapi kecelakaan pada anak juga bukan sesuatu yang tiba-tiba, tidak dapat diprediksi atau karena nasib buruk. Hal itu semua sebenarnya bisa dicegah oleh orang dewasa di sekitarnya. Jika di sekolah atau dipenitipan anak hal ini bisa di cegah oleh guru atau pengasuh anak, jika di rumah bisa dicegah oleh orang tua (Khatatbeh, 2016; Water, Natora, Stokes, 2009)

Pencegahan dan pertolongan pertama pada kecelakaan sangat penting dilakukan di sekolah dan di penitipan anak untuk menciptakan sekolah dan penitipan anak yang aman untuk anak-anak (Water, Natora, Stokes, 2009). Hal ini didukung juga oleh WHO dengan program safe community bahwa program ini meliputi segala usia di segala lingkungan dan situasi, lebih diarahkan ke pencegahan kecelakaan, meningkatkan kapasitas masyarakat untuk mencegah keselakaan, dan organisasi kesehatan menjadi peran penting dalam pelaksanaan program ini. Implikasi luasnya adalah bahwa dengan penguatan kapasitas yaitu peningkatan pengetahuan guru dalam mencegah kecelakaan serta melakukan P3K dapat diterapkan baik disekolah maupun di lingkungan rumah (Spinks, Turner, Nixon, McClure, 2009).

Kementrian kesehatan Republik Indonesia juga mendukung program safe community salah satunya dengan program UKS. Pelaksanaan UKS harus diwajibkan di setiap sekolah dan madrasah mulai dari TK/RA sampai SMA/ SMK/MA, mengingat UKS merupakan wadah untuk mempromosikan masalah kesehatan. Wadah ini menjadi penting dan strategis, karena pelaksanaan program melalui UKS jauh lebih efektif dan efisien serta berdaya ungkit lebih besar (Kemenkes, 2015). Penyuluhan tentang pencegahan serta pertolongan pertama pada kecelakaan merupakan bagian dari promosi kesehatan.

Berdasarkan survey yang dilakukan di Children Center Brawijaya Smart School (CC BSS), di sekolah tersebut sudah ada UKS, tapi pelaksanaannya belum optimal hanya skrining kesehatan, ruang UKS, sedangkan untuk program pencegahan kecelakaan dan pertolongan pertama pada kecelakaan (P3K) belum pernah dilakukan.

CC BSS merupakan sekolah Taman Kanak-Kanak (TK), Kelompok Bermain (KB) dan Penitipan Anak di lingkungan universitas brawijaya. Anak yang dititipkan di CC BSS minimal berusia 2 tahun dan maksimal 7 tahun. Anak-anak yang dititipkan dan sekolah di CC BSS sebagian besar anak dari staf Universitas Brawijaya (UB) dari semua fakultas, tidak terkecuali dari Fakultas Kedokteran UB dengan jumlah siswa kurang lebih 60 siswa. Ketika pulang sekolah terkadang anak-anak tersebut tidak segera di jemput sehingga guru-guru harus menemani sambil mengerjakan tugas lainnya. Tidak jarang anak-anak juga bermain dan berlari-lari yang tidak semua guru bisa mengawasi. Hal ini mengakibatkan ada anak yang jatuh dan mengalami cedera namun pertolongan pertama yang diberikan ada yang tidak tepat pada anak yang jatuh.

Adanya fenomena tersebut maka kami sebagai tenaga kesehatan yang dekat dengan CC BSS berupaya untuk ikut serta mewujudkan program pemerintah dalam meningkatkan peran UKS untuk keamanan siswa dan guru yang ada di sekolah tersebut. Kegiatan ini bertujuan untuk menggali permasalahan guru dalam melakukan pencegahan dan P3K, memberikan penyuluhan atau edukasi tentang pencegahan kecelakaan dan P3K sebagai bagian dari propram UKS pada staf guru dan pengasuh anak CC BSS sesuai dengan perkembangan ilmu kegawatdaruratan.

\section{Metode}

Kegiatan ini dilakukan pada bulan November 2017- April 2018 di CC BSS UB. Metode yang digunakan dalam kegiatan ini yaitu (1) diskusi eksplorasi cedera yang sering terjadi di sekolah dan analisis masalah yang dihadapi oleh CC BSS terkait kegawatdaruratan di dalam sekolah, (2) penyuluhan dan pelatihan tentang P3K dengan alat minimal yang ada di sekolah. Peserta yang ikut serta dalam kegiatan ini yaitu guru CC BSS Ub sebanyak 10 orang.

Materi edukasi yang diberikan yaitu pengetahuan dan ketrampilan P3K pada kasus demam, sesak nafas, mimisan, dan luka bakar, luka abrasi, penghentian perdarahan, pembalutan luka, pemasangan bidai. Kegiatan dilakukan selama empat kali pertemuan, seminggu sekali. Masing masing pertemuan durasinya selama dua jam. Pertemuan pertama pengisian kuesioner awal dan diskusi tentang analisis masalah dan menggali praktik pencegahan serta P3K yang telah dilakukan. Pertemuan kedua membahas tentang 
demam, mimisan, sesak nafas. Pertemuan ketiga membahas tentang luka bakar, penghentian perdarahan, pembalutan luka dan pemasangan bidai. Pertemuan ke empat dilakukan evaluasi dengan pengisian kuesioner.

Evaluasi keberhasilan dilakukan berdasarkan indicator sebagai berikut :

Tabel 1. Indicator dan Evaluasi kegiatan

\begin{tabular}{|c|c|c|c|}
\hline No. & Kegiatan & Indikator & Evaluasi \\
\hline 1. & $\begin{array}{l}\text { Diskusi eksplorasi cedera } \\
\text { yang sering terjadi di } \\
\text { sekolah dananalisis masalah } \\
\text { dan menggali permasalahan } \\
\text { dalam melakukan praktik } \\
\text { pencegahan dan P3K }\end{array}$ & $\begin{array}{l}\text { Guru dapat menyebutkan } \\
\text { cedera yang sering terjadi di } \\
\text { sekolah } \\
\text { Adanya masalah yang dapat } \\
\text { didentifikasi oleh para guru. } \\
\text { Indentifikasi praktik } \\
\text { pencegahan kecelakaan di } \\
\text { sekolah } \\
\text { Kuesioner awal terisi }\end{array}$ & $\begin{array}{l}\text { Guru-guru mampu } \\
\text { mengidentifikasi masalah dalam } \\
\text { P3K. } \\
\text { Guru-guru telah melakukan } \\
\text { praktik pencegahan kecelakaan } \\
\text { dengan baik } \\
\text { Kuesioner terisi oleh } 10 \text { guru }\end{array}$ \\
\hline 2 & Pelatihan P3K di sekolah & $\begin{array}{l}\text { Peningkatan pengetahuan dan } \\
\text { ketrampilan }\end{array}$ & $\begin{array}{l}\text { Peningkatan skor pengetahuan } \\
\text { dan ketrampilan tentang P3K } \\
\text { pada kasus perdarahan, } \\
\text { pembalutan luka, memar, dan } \\
\text { mimisan }\end{array}$ \\
\hline 3 & Evaluasi kegiatan & $\begin{array}{l}\text { Kuesioner setelah kegiatan } \\
\text { terisi. } \\
\text { Tergalinya perasaan guru- } \\
\text { guru setelah mengikuti } \\
\text { kegiatan }\end{array}$ & $\begin{array}{l}\text { Kuesioner terisi lengkap oleh } 10 \\
\text { guru. } \\
\text { Terdapat perasaan yang positif } \\
\text { dari guru-guru mengenai } \\
\text { kegiatan ini. Mereka menjadi } \\
\text { lebih percaya diri ketika } \\
\text { melakukan P3K. }\end{array}$ \\
\hline
\end{tabular}

\section{Hasil dan pembahasan}

Diskusi eksplorasi kejadian cedera disekolah dan praktik pencegahan kecelakaan oleh guru Berikut ini adalah jenis cedera yang sering terjadi di sekolah, satu orang guru bisa menjawab lebih dari satu jenis cedera.

Table 2. Jumlah kejadian cedera yang sering terjadi di sekolah

\begin{tabular}{lll}
\hline Jenis cedera & Jumlah & Presentase (\%) \\
\hline Jatuh & 8 & 28 \\
Terbentur & 8 & 28 \\
Lecet/abrasi & 3 & 10 \\
Memar & 4 & 14 \\
Luka robek & 2 & 7 \\
Mimisan & 1 & 3 \\
Luka sayat & 1 & 3 \\
Terjepit & 2 & 7 \\
Jumlah & 29 & 100 \\
\hline
\end{tabular}

dari 10 guru yang berpartisipasi dalam program ini, semua menjawab lebih dari satu dan ada 29 jawaban tentang jenis cedera yang sering terjadi di sekolah. Cedera yang paling banyak adalah jatuh dan memar (28\%). Kejadian cedera sering terjadi ketika bermain di halaman sekolah, di ruang kelas dan ketika bermain sepulang sekolah. 
Tabel 3. Praktik pencegahan kecelakaan disekolah

\begin{tabular}{lllll}
\hline Keterangan & $\begin{array}{l}\text { Praktik } \\
\text { pencegahan } \\
\text { kecelakaan } \\
\text { sekolah }\end{array}$ & Nilai max & Nilai min & $\begin{array}{l}\text { Nilai signifikansi } \\
\text { (Wilcoxon signed } \\
\text { rank test) }\end{array}$ \\
\hline Rata-rata skor pre tes & 9,09 & 9,8 & 8,3 & 0,725 \\
Rata rata skor Post tes & 9,2 & 9,7 & 8,6 & \\
\hline
\end{tabular}

Table 3 menunjukkan bahwa skor praktik pencegahan yang dilakukan sebelum dan sesudah diberi penyuluhan sudah baik ( skor maksimal adalah 10), hasil analisis SPSS 21 dengan wilcoxon signed rank test menunjukkan tidak ada perubahan yang signifikan karena sebelum penyuluhan, mereka telah melakukan praktik pencegahan dengan sangat baik.

Praktik pencegahan yang mereka lakukan sesuai hasil diskusi kelompok terfokus yaitu mereka selalu memodifikasi lingkungan misalnya menyimpan benda tajam seperti pisau dapur di lemari yang terkunci. Untuk mencegah anak-anak terpeleset ketika cuci tangan selalu disiapkan alat pel dan selalu mengawasi ketika siswa beraktivitas, menerapkan aturan ketika bermain di halaman serta selalu mengingatkan siswa untuk selalau berhati-hati dalam bermain. Pencegahan dipenitipan juga dilakukan dengan cara menyiapkan air mandi yang hangat sebelum siswa penitipan anak di mandikan, sehingga ketika siswa penitipan masuk kamar mandi sudah tidak ada air panas.

\section{Pengetahuan tentang P3K sebelum dan sesudah dilakukan penyuluhan}

Tabel 4. Pengetahuan P3K sebelum dan sesudah penyuluhan

\begin{tabular}{|c|c|c|c|c|c|}
\hline Keterangan & $\begin{array}{l}\text { Rata-rata } \\
\text { skor }\end{array}$ & $\begin{array}{l}\text { nilai } \\
(95 \%)\end{array}$ & $\max$ & nilai Min ( 95\%) & $\begin{array}{l}\text { Nilai } \\
\text { signifikansi } \\
\text { (Wilcoxon signed rank } \\
\text { test) }\end{array}$ \\
\hline Pre tes & 6,1 & 6,7 & & 5.3 & 0,00 \\
\hline post tes & 8,5 & 9,2 & & 7,29 & \\
\hline
\end{tabular}

Tabel 4 menunjukkan bahwa terjadi peningkatan pengetahuan yang signifikan pada guru-guru peserta penyuluhan. Materi penyuluhan mencakup penghentian pendarahan, penatalaksanaan memar, pembalutan luka, mimisan, pembidaian, dan penatalaksanaan kegawatan ringan seperti demam. Jika dilihat dari indicator pada tabel 1 , kondisi setelah penyuluhan terdapat peningkatan skor sesuai dengan indicator.

\section{Pembahasan}

Hasil diskusi dan kuesioner menunjukkan bahwa cedera yang sering terjadi di sekolah adalah jatuh (28\%) dan terbentur mainan, pintu atau temannya (28\%). Luka yang sering terjadi yaitu memar (14\%) dan abrasi (10\%). Kejadian cedera sering terjadi ketika bermain dihalaman sekolah, di ruang kelas, dan ketika bermain sepulang sekolah. Ganfure, Ameya, Tamirat, Lencha, \& Bikila, (2018) juga menyebutkan bahwa kejadian kegawatdaruratan banyak terjadi di taman bermain, dan saat siswa pulang sekolah. Selain itu Ibrahim, A., Sam-Agudu, N., Omaye, U., Ushie, B., Olumide, A., Omotade, O. (2016) menyebutkan bahwa kondisi sekolah di negara berkembang banyak yang kurang optimal dalam keamanan untuk siswa sehingga berisiko untuk menimbulkan cedera.

Cedera yang terjadi disebabkan oleh ketidakhati-hatian anak-anak dalam bermain. Cedera sering terjadi pada anak-anak karena karakter anak-anak yang suka mencoba hal baru, perkembangan tubuhnya yang belum optimal dan kurangnya kewaspadaan terhadap lingkungan. Hal ini juga diungkapkan oleh Ganfure, Ameya, Tamirat, Lencha, \& Bikila, (2018) bahwa cedera pada anak disebabkan oleh kondisi tumbuh kembangnya yang rentan terhadap cedera.

Cedera ini bisa dicegah agar tidak terjadi cedera yang berakibat fatal. Menurut hasil diskusi dengan para guru, mereka sebenarnya telah melakukan tindakan pencegahan dengan sangat baik. Sebagai contoh, mereka menerapkan pencegahan di tempat cuci tangan dengan memberikan gambar untuk segera mengeringkan tangan setelah cuci tangan, menyimpan benda-benda tajam (pisau) di loker terkunci di dalam dapur, menyiapkan air hangat untuk mandi dan memasukkan anak ke kamar mandi untuk mandi ketika air hangat sudah siap dan api kompor sudah mati. Selain itu para guru juga sudah melakukan pengawasan ketika anak-anak bermain, menetapkan aturan bermain dan selalu mengingatkan anak-anak untuk berhati hati saat bermain. Hal tersebut dilakukan ketika suatu kondisi ruangan atau tempat 
bermain tidak mungkin di modifikasi. Studi dari Zhou, Zhou, Zhi-Hua, Qiong-Yue, (2016) menggunakan tindakan pencegahan kecelakaan dengan cara membuat gambar-gambar untuk edukasi, poster pencegahan jatuh, menyebarkan brosur dapat mengurangi kejadian cedera di sekolah dasar di Xining City China.

Permasalahan yang sering dihadapi adalah guru-guru belum tahu pasti tentang P3K di sekolah, dan obat-obatan yang boleh diberikan. Mereka mendapatkan pengetahuan hanya dari internet, sehingga belum pasti kebenarannya. Skor pengetahuan guru sebelum diberikan pelatihan yaitu 6,1. Skor pengetahuan sebelum pelatihan tergolong rendah. Poin yang banyak terdapat kesalahan yaitu penanganan luka abrasi sebagian besar tidak langsung di cuci dengan air mengalir dan sabun tetapi dibersihkan dengan povidon iodine dan rivanol. Kemudian penanganan mimisan dilakukan dengan cara mendongakkan kepala, penangan luka bakar dengan di beri pasta gigi. Hal ini sejalan dengan penelitian Ganfure, Ameya, Tamirat, Lencha, \& Bikila, (2018) bahwa para guru memiliki skor yang rendah tentang pengetahuan P3K. Selain itu mereka juga menyebutkan bahwa pengetahuan mereka didapatkan dari tenaga kesehatan profesional, namun selain itu juga dari internet, buku dan dari teman sejawat. Li, Jiang, Jin, Qiu, \& Shen, (2012) juga menyebutkan bahwa pengetahuan guru Taman kanak-kanak (TK) tentang P3K juga rendah. Hal ini membutuhkan pelatihan P3K atau edukasi untuk mereka.

Dengan pelatihan yang efektif skor pengetahuan guru tentang P3K bisa meningkat menjadi 8,5. Terdapat perbaikan pengetahuan mengenai beberapa poin yang memiliki nilai rendah pada saat pre test terutama poin penanganan kejadian alergi, perdarahan, mimisan dan kecelakaan luka bakar. Selain itu guru merasa terbantu dengan adanya kegiatan pengabdian masyarakat karena update atau pelatihan P3K bagi guru belum pernah dilakukan, dan dari Puskesmas belum ada pembinaan tentang P3K. Arli \& Yildirim (2017) menyebutkan dalam penelitian eksperimen pada 24 orang guru kelompok intervensi, dan 20 orang guru kelompok kontrol bahwa pelatihan P3K pada guru sangat efektif dalam meningkatkan tingkat pengetahuan mereka.

Guru merupakan orang yang terdekat dengan anak-anak ketika di sekolah. Ketika guru tidak dapat memberikan pertolongan pertama ketika ada kegawatdaruratan mereka merasa bingung. Bingung yang mereka rasakan karena tidak tahu prosedur yang tepat dan keadaan anak yang menangis dan terkadang anak meminta perawatan sesuai pilihan mereka. Sebagai contoh ketika ada anak yang jatuh dengan luka abrasi, beberapa anak tidak mau luka nya di cuci, padahal pencucian luka harus dilakukan untuk menghilangkan kotoran. Melihat keadaan tersebut guru terpaksa mengikuti kemauan anak agar anak tidak menangis dan karena tidak mengetahui alasan yang benar tentang pencucian luka.

Pelatihan P3K dapat meningkatkan pengetahuan mereka tentang prosedur P3K dan rasional dari semua tindakannya. Sehingga mereka lebih percaya diri dalam memberikan penjelasan kepada anak-anak. Ketika guru merasa percaya diri maka anak pun akan percaya ketiak guru memberikan pemahaman dan bersedia untuk dirawat sesuai tindakan yang benar agar cedera tidak menjadi lebih parah. Arli \& Yildirim (2017) juga menyatakan bahwa dengan pengetahuan yang baik maka P3K dapat mencegah kematian dan cedera lebih lanjut.

Dengan adanya pelatihan P3K guru berharap adanya sinkronisasi antara di sekolah dan di rumah. Sehingga pelatihan tidak hanya di berikan kepada guru saja tetapi juga orang tua. Ketika di rumah yang berperan menjaga anak-anak adalah orang tua, sehingga orang tua juga harus diberi edukasi tentang P3K.

\section{Simpulan dan saran}

Praktik pencegahan kecelakaan yang dilakukan oleh guru di CC BSS UB sudah sangat baik. Hal yang masih menjadi kendala adalah pengetahuan mereka tentang P3K masih belum baik. Dengan adanya pelatihan selama 4 kali dapat meningkatkan pengetahuan dna kepercayaan diri mereka. Sehingga mereka dapat melakukan tindakan P3K dengan tepat dan mencegah cedera lebih lanjut. Penyamaan persepsi dengan orang tua terkait P3K diperlukan agar apa yang telah dilakukan disekolah dapat juga dilakukan di rumah agar anak bias aman dimanapun mereka berada. Kami menyampaikan terimakasih kepada CC BSS UB yang bersedia berpartisipasi dalam kegiatan ini, serta dari Badan Penelitian dan Pengabdian kepada Masyarakat Fakultas edokteran Universitas Brawijaya yang telah mendanai kegiatan ini.

\section{Daftar Rujukan}

Adi , Banu Setyo. 2014. "Pemahaman Guru Tentang Pertolongan Pertama Pada Kecelakaan”. Jurnal PPSD FIP UNY vol 2 no 1.

Ganfure, G., Ameya, G., Tamirat, A., Lencha, B., \& Bikila, D. (2018). First aid knowledge, attitude, practice, and associated factors among kindergarten teachers of Lideta sub-city Addis Ababa, Ethiopia. PLoS 
ONE, 13(3), 1-16. https://doi.org/10.1371/journal.pone.0194263

Karadag Arli, S., Professor, A., Yildirim, Z., \& Senay Karadag Arli, A. (2017). The Effects of Basic First Aid Education on Teachers' Knowledge Level: A Pilot Study. International Journal of Caring Sciences May, 10(2), 2-813. Retrieved from www.internationaljournalofcaringsciences.org

Li, F., Jiang, F., Jin, X., Qiu, Y., \& Shen, X. (2012). Pediatric first aid knowledge and attitudes among staff in the preschools of Shanghai, China. BMC Pediatrics, 12, 1-8. https://doi.org/10.1186/1471-2431-12121

Zhou, M., Zhou, S., Zhi-Hua, X., Qiong-Yue, S. (2016). Intervention to reduce injuries among student in primary and secondary schools in Xining City. Abstract. Injury Prevention. 22 (Suppl 2):A1-A397

Ibrahim, A., Sam-Agudu, N., Omaye, U., Ushie, B., Olumide, A., Omotade, O. (2016). Impact of first aid training on the first aid knowledge and skills capacity of primary school teachers in Ibadan, Nigeria. Abstract. Injury Prevention. 22 (Suppl 2):A1-A397

Khatatbeh M. First aid knowledge among University students in Jordan. Int J Prev Med 2016;7:24.

Kemenkes, 2015. Rencana strategis Kemenkes http://www.depkes.go.id/resources/download/infopublik/Renstra-2015.pdf

Lindqvist K, Timpka T, Schelp L and Risto O. Evaluation of a child safety program based on the WHO Safe Community model. Inj. Prev. 2002;8;23-26 doi:10.1136/ip.8.1.23

Spinks A, Turner C, Nixon J, McClure RJ. The 'WHO Safe Communities' model for the prevention of injury in whole populations. Cochrane Database of Systematic Reviews 2009, Issue 3. Art.No.: CD004445. DOI: 10.1002/14651858.CD004445.pub3

Water M, Natora A, Stokes M, Kidsafe, 2009. Family Day Care Child Safety Guidelines 2009. Melbourne : Service Development Division Department of Education and Early Childhood Development 